\title{
Acute and Chronic Toxicity Studies of Ethanol Leaf Extract of Merremia Tridentata (Linn) Hallier F.
}

\author{
Olubodun A. Adebiyi, Danladi A. Ameh, Elewechi Onyike, and Dorcas B. James
}

\section{ABSTRACT}

The acute and chronic toxicity evaluation of Ethanol leaf extract of Merremia tridentata (Linn) Halier F. (MTELE) was carried out on albino wistar rats. Phytochemical screening and acute toxicity profile of the extract were determined using standard methods. The animals were assigned into groups and administered varying doses of MTELE $(100,200,400 \mathrm{mg} / \mathrm{kg}$ body weight and $0.2 \mathrm{ml}$ of distilled water) for a period of hundred days (fourteen weeks). The body weight, relative organ weight, haematology, serum biochemical indices and histopathological studies of the liver, kidney, spleen, heart, and lungs were appropriately carried out to determine propensity of possible toxicity. Phytochemical screening revealed the presence of alkaloids, tannins, cardiac glycosides, saponins, steroids, triterpenes, flavonoids while anthraquinone and cyanogenic glycosides were absent. The median lethal dose $L_{50}$ was estimated as $2200 \mathrm{mg} / \mathrm{kg}$ body weight. There was significant $(\mathbf{p}<0.05)$ reduction in the percentage change in body weight of rats administered 200 and $400 \mathrm{mg} / \mathrm{kg} / \mathrm{day}$ dose of the extract for 100days when compared to the control group. Moreover, there was a significant $(p<0.05)$ reduction in the relative weight of the spleen of rats and significant $(p<0.05)$ increase in the relative weight of the liver, kidney, heart and lungs of rats administered $400 \mathrm{mg} / \mathrm{kg} / \mathrm{day}$ dose. All serum biochemical parameters studied showed significant $(p<0.05)$ increase in group administered $400 \mathrm{mg} / \mathrm{kg}$ body weight dose while alkaline phosphatase, aspartate amino transferase, creatine kinase, lactate dehydrogesase and potassium ion showed significant increase $(p<0.05)$ in the group administered $200 \mathrm{mg} / \mathrm{kg} / \mathrm{day}$. There is no significant change in hematological parameters like RBC, hemoglobin, hematocrit, platelets, monocytes, basophils, MCV, MCH, MCHC, in the extract treated animals except the lymphocyte that showed a significant $(p<0.05)$ reduction only in the group treated with $400 \mathrm{mg} / \mathrm{kg}$ body weight dose. Administration of MTELE at $200 \mathrm{mg} / \mathrm{kg}$ body weight did not occasioned any histoarchitectural change in the liver and spleen but caused varying degree of remarkable histological derangement in the other tissues. Furthermore, there were remarkable pathologies in the liver, kidney, spleen, heart and lungs ranging from vascular congestion, haemorrhage, fibrosis, to renal and myocardial damage in the group treated with $400 \mathrm{mg} / \mathrm{kg} / \mathrm{day}$ dose for hundred days. However, $100 \mathrm{mg} / \mathrm{kg}$ body weight dose showed no significant difference $(p>0.05)$ in all the parameters evaluated indicating safety at this dosage. Ethanol leaf extract of Merremia tridentata (Linn) Halier F. (MTELE) may not be safe at chronic administration even at dosage as low as $200 \mathrm{mg} / \mathrm{kg}$ body weight. The plant should be cautiously employed to avoid unwarranted complication on long term administration.

Keywords: Acute toxicity, Chronic toxicity, Evaluation, Merremia tridentata (linn) Halier F.

\section{INTRODUCTION}

Medicinal plants have come to play important role as therapeutic alternative in many parts of the world. This paradigm shift has opened new frontier in global healthcare delivery with companies making fortune from these plants based on their folklorish use by herbal practitioners through the ages. Merremia tridentata (Linn) Halier $F$. family (Convolulacea) is a plant found in wasteland as perennial shrub. It is a tropical climbing herb with thick rootstock spreading on walls and fences. In Nigeria, the plant is found
Published Online: July 14, 2021

ISSN: $2684-4478$

DOI : 10.24018/ejchem.2021.2.3.62

O. A. Adebiyi*

Department of Biochemistry, Ahmadu Bello University, Zaria, Nigeria.

(e-mail: olubodunadebiyi@ gmail.com)

D. A. Ameh

Department of Biochemistry, Ahmadu

Bello University, Zaria, Nigeria.

(e-mail: danladiameh@yahoo.com)

E. Onyike

Department of Biochemistry, Ahmadu Bello University, Zaria, Nigeria.

(e-mail: elewechi2003@yahoo.com.)

D. B. James

Department of Biochemistry, Ahmadu Bello University, Zaria, Nigeria.

(e-mail: dbjams16187@yahoo.com)

*Corresponding Author

mainly in the North eastern and North western regions where it is employed in the treatment of scorpion sting, diabetes, and sugar related diseases, urinary and known locally as Yambururu in Hausa language [1]. The plant has been reported to be employed in traditional systems of medicine for treatment of various ailments such as piles, swellings, ulcers, rheumatic affections, stiffness of the joints, hemiplegia, urinary infections, and general debility [2], [3]. Reference [4] reported the anti-inflammatory capacity of the root extract of the plant. Analgesic and anti-inflammatory activities of these extracts were assessed in rats with hot plate 
test, writhing test in mice, carrageenan induced paw oedema and histamine induced paw edema in rats. Also, study on the anti-diabetic effect of the aqueous root extract of $M$. tridentata had been carried out [5] and the aerial parts were reported to contain flavonoids, diosmetin, luteolin, and their $7-O$ - $\beta$-D-glucosides [2] imparting on its antioxidant and free radical scavenging activities [3]. Other previous studies stated that $M$. tridentata have strong wound healing, antiinflammatory, and anti-arthritic activities [6], [7]. Reference [8] reported that $M$. tridentata was used as a supplementary feed to the grass Panicum maximum for young West African Dwarf Sheep. However, in our literature search, there was no record on the safety of the plant especially on the long term hence the present study is aimed at investigating the acute and chronic toxicity profile of Merremia tridentata ethanol leaf extract (MTELE).

\section{MATERIALS AND METHOD}

\section{A. Plant Material and Extraction}

The aerial part of Merremia tridentata was collected from the bank of Tamburawa river along Zaria road Kano Nigeria. and was authenticated at the Herbarium unit of Botany department of Ahmadu Bello University Zaria, Nigeria. The plant material was shade dried for three weeks to allow the leaves to drop from the stem and pulverized using a kitchen blender. The powdered leaf sample was cold macerated using $70 \%$ ethanol for seventy two hours after which the solvent was evaporated using Rotary Vacuum Evaporator (Hahn Vapor, HS-2005V, Hahnshin Scientific Co., Korea) to obtain the Merremia tridentata ethanol leaf extract (MTELE) used for this study.

\section{B. Animals}

Healthy adult albino male rats weighing 100 to $150 \mathrm{~g}$ were obtained from National Animal Production and Research Institute (NAPRI, Vom, Nigeria) were grouped and housed in cages under 12 hours light dark cycle at $34 \pm 2{ }^{\circ} \mathrm{C}$ with free access to standard pellet diet and water ad libitum. The animals were allowed to acclimatize to the laboratory conditions for two weeks prior to the commencement of the experiment.

\section{Chemicals}

All chemicals and reagents used in this study are of analytical grade. Kits for estimation of biochemical parameters (Protein, Albumin, Creatinine, ALT, AST, ALP, LDH, Creatine kinase) are product of RANDOX Laboratory Ltd. Ardmore United Kingdom.

\section{Acute Toxicity Study}

The toxicity test was carried out on albino rats (100-120 g) in accordance with the protocol of Reference [9]. On the first phase, animals were grouped into three of three rats per group and administered 10, 100 and $1000 \mathrm{mg} / \mathrm{kg}$ body weight doses respectively of MTELE orally and monitored for twenty four hours for signs of toxicity like, tremor, restlessness, lacrimation, dizziness and death. In the second phase, another set of rats (one per group) were given oral dose of MTELE at $1200,1600,2900$ and $5000 \mathrm{mg} / \mathrm{kg}$ respectively and monitored for twenty four hours for signs of toxicity. The
Median lethal dose $\left(\mathrm{LD}_{50}\right)$ was estimated from the Geometric Mean of the Maximum dose survived by all the rats and the minimum dose that caused fatality in all rats in the experiment [9].

\section{E. Experimental Design for Chronic Toxicity Study}

Albino male rats weighing $120 \pm 20 \mathrm{~g}$ was divided into four cages of five rats in each cage. They were placed on rat chow and allowed to drink water ad libitum. Group I was administered distilled water as the control while the remaining groups were administered specified doses of MTELE orally once a day for a period of fourteen weeks.

The treatments were as follows:

Group I: Normal rats treated with $0.2 \mathrm{ml}$ distilled water.

Group II: Normal rats administered with $100 \mathrm{mg} / \mathrm{kg}$ body weight MTELE

Group III: Normal rats administered with $200 \mathrm{mg} / \mathrm{kg}$ body weight MTELE

Group IV: Normal rats administered with $400 \mathrm{mg} / \mathrm{kg}$ body weight MTELE

\section{F. Body Weight, Relative Organ Weight and Feed Intake}

The body weights of the animals in each group were recorded on weekly basis while the water and feed intake were recorded on daily basis all through the period of the experiment. On the 101st day, at the end of the experimental period for chronic studies, animals in all the groups were weighed and sacrificed by cervical decapitation after anaesthetizing them with Chloroform. Blood was collected in EDTA tube and plain tubes for the analysis of hematological and biochemical parameters respectively [10]. The sacrificed animals were dissected to harvest organs such as the liver, spleen, kidney, heart, and the lungs. These organs were washed with ice cold saline blotted dry and weighed.

\section{G. Haematology and Biochemical Analysis}

Blood samples collected on the day after the expiration of 100day administration of MTELE into EDTA container for hematological estimation were analyzed using auto Hematology Analyzer (Mindray, BC-2800) while blood for biochemical estimations collected in plain specimen bottles was centrifuged at $3000 \mathrm{rpm}$ for 10 minutes to obtain the serum for analysis. Serum total protein, albumin, alanine amino transferase (ALT), aspartate amino transferase (AST), bilirubin (total and direct), alkaline phosphatase, urea, uric acid, creatinine, creatine kinase and lactate dehydrogenase levels were measured using biochemical assay kits (RANDOX Laboratory Ltd. Ardmore United Kingdom). Serum electrolytes (Sodium and Potassium ions) were estimated using the method described by [11].

\section{H. Histopathological Examination}

The liver, kidney, heart, lungs, and spleen were removed and fixed in $10 \%$ formol saline. The fixed tissues were transferred to a graded series of ethanol and then cleared in xylene. Once cleared, the tissues were infiltrated in molten paraffin wax in the oven at $58{ }^{\circ} \mathrm{C}$. Serial section of 5 micrometers thick were obtained from a solid block of tissue, cleared, fixed in clean slides, stained with Haematoxylin and Eosin stains, and examined with the light microscope [12]. 


\section{Statistical Analysis}

Results were expressed as mean \pm SD. All data was subjected to one-way analysis of variance (ANOVA) and Tukey's post hoc test at $95 \%$ level of significance using MINITAB 17 statistical software.

\section{RESULTS}

\section{A. Phytochemical Screening}

The extract was found to contain the following secondary metabolites: Alkaloids, tannins, cardiac glycosides, saponins, steroids, triterpenes, flavonoids while anthraquinone and cyanogenic glycosides are absent (Table I).

\section{B. Acute Toxicity Test}

The result of the acute toxicity test is shown in Table II. In the first phase of the experiment, there was no mortality of any of the rats at 10,100 and $1000 \mathrm{mg} / \mathrm{kg}$ body weight dose while mortality was only recorded at $5000 \mathrm{mg} / \mathrm{kg}$ body weight dose. The median lethal dose was estimated at $2200 \mathrm{mg} / \mathrm{kg}$ body weight.

\section{Effect of Different Doses on Body Weight Upon Chronic Administration}

The change in weight of rat administered $100 \mathrm{mg} / \mathrm{kg}$, $200 \mathrm{mg} / \mathrm{kg}$ and $400 \mathrm{mg} / \mathrm{kg}$ of MTELE is shown in Figure 1. There was no significant $(p>0.05)$ difference in the mean body weight of the different treatment groups treated with the leaf extract of $M$. tridentata until after twelve weeks of treatment. Significant $(\mathrm{p}<0.05)$ difference in the weight gained in rats especially between the group treated with $400 \mathrm{mg} / \mathrm{kg}$ body weight dose and the control group from the thirteenth week was observed. The group administered with $200 \mathrm{mg} / \mathrm{kg}$ body weight of MTELE only had a significant $(\mathrm{p}<0.05)$ difference in weight gained at the fourteenth week.

\section{Effect of the Different Doses of MTELE on Relative Organ Weight upon Chronic Administration}

Administration of MTELE at two dosage levels tested (100 and $200 \mathrm{mg} / \mathrm{kg}$ body weight) did not caused any notable difference in the relative weight of the liver, kidney, lung, and heart (Table III). However, there was a significant $(\mathrm{p}<0.05)$ reduction in the relative weight of the spleen of rats administered $400 \mathrm{mg} / \mathrm{kg}$ body weight dose (Group IV) and significant increase $(p<0.05)$ in the relative weight of the liver, kidney, heart, and lungs of rat administered $400 \mathrm{mg} / \mathrm{kg} /$ day doses of MTELE for a period of fourteen weeks.

A. Effect of the Different Doses of MTELE on Heamatology and Serum Biochemical Parameter upon Chronic Administration

The extract did not cause any alteration in the haematological parameters at all the dosages administered whereas the extract at $400 \mathrm{mg} / \mathrm{kg}$ body weight dose caused a significant $(p<0.05)$ alteration in all the biochemical parameters investigated in this study. Furthermore, there was also significant increase in the serum level of potassium ion and activity of alkaline phosphatase, aspartate amino transferase, creatine kinase and lactate dehydrogenase in the group administered $200 \mathrm{mg} / \mathrm{kg}$ body weight of MTELE when compared with the control group after hundred days of administration (Table VI).

On the biomarkers of kidney function, the ethanolic leaf extract caused a significant $(\mathrm{p}<0.05)$ increase in the blood urea, creatinine and Potassium at $200 \mathrm{mg} / \mathrm{kg}$ and $400 \mathrm{mg} / \mathrm{kg}$ body weight. The extract also caused a significant $(\mathrm{p}<0.05)$ reduction in serum concentration of sodium at $400 \mathrm{mg} / \mathrm{kg}$ body weight. Furthermore, the extract elicited a significant $(p<0.05)$ increase in the level of creatine kinase and lactate dehydrogenase in the serum of the rat groups administered 200 and $400 \mathrm{mg} / \mathrm{kg}$ body weight doses of MTELE. The extract however did not show any effect different from the control group upon administration at $100 \mathrm{mg} / \mathrm{kg}$ dose level.

B. Effect of the Different Doses of MTELE on Histoarchitecture of Liver, Kidney, Heart, Spleen and Lungs upon Chronic Administration

Liver, kidney, heart, lung, and spleen of rat treated with $100 \mathrm{mg} / \mathrm{kg}$ body weight dose of extract showed no remarkable pathology when compared to the control group. However, the liver from the group of rats administered $200 \mathrm{mg} / \mathrm{kg}$ body weight dose of extract for hundred days (fourteen weeks) showed unremarkable histo-architecture (Plate 1c) while the liver architecture from the $400 \mathrm{mg} / \mathrm{kg}$ body weight dose group showed a vast area of vascular congestion (Plate 1d). Moreover, the kidney of rat administered $200 \mathrm{mg} / \mathrm{kg}$ body weight dose of extract showed areas of haemorrhage and vascular congestion (Plate 2c) while the architecture of kidney of rat administered $400 \mathrm{mg} / \mathrm{kg}$ body weight dose for a period of 100 days revealed haemorrhage, vascular congestion, and renal damage (Plate 2d). There was no damage done to the spleen by the administration of MTELE at the different dose levels until $400 \mathrm{mg}$ /day where fibrosis was conspicuously noticed (Plate $3 \mathrm{~d}$ ). The heart, which is another important organ in the living system reacted to the administration of MTELE by developing heamorrhage and vascular congestion at $200 \mathrm{mg} / \mathrm{kg}$ body weight dose and haemorrhage with myocardial damage at $400 \mathrm{mg} / \mathrm{kg} / \mathrm{day}$ dose level. The Photomicrographs of the lung of rats administered $200 \mathrm{mg} / \mathrm{kg}$ and $400 \mathrm{mg} / \mathrm{kg}$ dose of tridentata leaf extract however showed areas of haemorrhage and vascular congestion (Plate 5c and d).

\section{DISCUSSION}

Herbal medicine is well accepted as alternate source of treatment globally with the major constraint of the knowledge of the safe therapeutic dose especially in treatment involving a considerable length of time. The absence of scientific validation and toxicity evaluation had really called for concern in the use of plant extracts for quality health care delivery. Thence it is necessary to carry out toxicity evaluation of these plants with the intention to ascertain their safety at short and long term. It is the result of the toxicity testing using modern scientific medium that determines the acceptability and/or safety of use or otherwise of the extract. Toxicological studies had been carried out on a number of natural extracts [13]-[17]. In this study, the median lethal dose of MTELE (2200 mg/kg body weight) signifies that the extract is not entirely safe upon administration; low toxicity by interpretation [18]. The extract is made up of alkaloids, 
carbohydrate, cardiac glycosides, flavonoids, sapponins, steroids, tannins, and triterpenes. These phyto-constituents are known to possess an array of therapeutic properties ranging from antimicrobial, antiviral, antihelmintic, antifungi, antidiabetic, immunostimulatory, antidepressant, antitumour, lipemic, anti-inflammatory to antisickling [19], [1], [10]. Some of these secondary metabolites have been reported to be toxic in some experimental studies [20]. Reduction in body weight and internal organ weight are considered as sensitive indices of toxicity after exposure to toxic substances [21], [22]. There was a significant $(p<0.05)$ reduction in the percentage change in weight of rats administered 200 and $400 \mathrm{mg} / \mathrm{kg}$ body weight dose of MTELE when compared with the control group. This may be as a result of deficit in nutrient utilization and bioavailability for a period thereby resulting in growth retardation of the experimental animals. This may be a pointer the possibility of toxicity of the extract to these animals on chronic exposure.

There was also a significant $(p<0.05)$ reduction in the relative organ weight of the spleen of rats administered $400 \mathrm{mg} / \mathrm{kg} / \mathrm{day}$, and increase in the relative weight of the liver, kidney, heart and lungs in rat treated with $400 \mathrm{mg} / \mathrm{kg} /$ day of MTELE for 100 days. The spleen is a blood-forming organ in early life and later a storage organ for red corpuscles and platelets; because of the large number of macrophages, it also acts as a blood filter, both identifying and destroying effete erythrocytes. The atrophy of the spleen as seen in the effect of $400 \mathrm{mg} / \mathrm{kg}$ dose of MTELE could be taken as the response to the noxious stimuli exerted by the dose causing serious challenge to the enormous functions of the spleen. The liver is an essential organ responsible for detoxification among other functions alongside the kidney which helps in the excretion of such unwanted substances from the body system. The lung is also very essential in the process of respiration for energy generation to sustain life and wholesome development. The discrepancies brought about by this extract will definitely affect these vital functions and consequently the well being of the animals. Organ weight analysis is an important endpoint for identification of potentially harmful effects of test compounds in toxicology studies [23]. Moreover, organ weight is one of the most sensitive indicators of an effect of test article, as significant differences in organ weight between treated and untreated (control) animals may occur in the absence of any morphological changes [24]. Hence in this study, the effect of the extract on the liver, heart, lungs, and spleen may be a pointer to its potential toxicity but needs further confirmation using other indicators.

There is no significant ( $\mathrm{p}>0.05)$ change in hematological parameters like RBC, hemoglobin, hematocrit, platelets, monocytes, basophils, MCV, MCH, MCHC, in the extract treated animals. Hematological change such as anemia is reported to be accompanied with bone marrow toxicity [25], [26]. The white blood cells did not also show any significant $(p>0.05)$ difference in all the treated groups when compared with the control. It was only the lymphocyte that showed a significant $(p<0.05)$ reduction only in the group treated with $400 \mathrm{mg} / \mathrm{kg}$ body weight dose. This may be as a result of the atrophy of the spleen at this dose level indicating the possibility of toxicity to immune-stimulatory functions. The observed values of blood parameters within the normal range suggest that the drug may be non-toxic in nature to the erythropoietic system at 100, 200 and $400 \mathrm{mg} / \mathrm{kg} / \mathrm{day}$.

Chronic exposure of the animals to the plant extract Meremia tridentata at $100 \mathrm{mg} / \mathrm{kg}$ dosage when tested for the biochemical parameters such as protein, urea, AST, ALT, LDH and creatinine do not show any significant difference in their levels when compared with the control animals. However, at higher dosage of $200 \mathrm{mg} / \mathrm{kg} /$ day for 100 days there were significant increase in the serum levels of alkaline phosphatase, aspartate amino transferase, lactate dehydrogenase and potassium ion while the group treated with $400 \mathrm{mg} / \mathrm{kg} /$ day manifested significant difference in serum levels of all the biochemical parameters investigated when compared with the control. The abnormal values of the biochemical parameters such as Urea and Creatinine suggest that the extract caused serious disturbance in the renal function. The transaminases (alanine amino transferase and aspartate amino transferase), creatine kinase, $\mathrm{LDH}$, and alkaline phosphatases are good indices of liver, heart, and kidney damage respectively [27]-[30], [10]. Hence, the raised levels of these serum biochemicals are indication of potential toxicity of the extract to the liver, heart, and the kidney. The chronic administration of the leaf extracts of Merremia tridentata (Linn) elicited responses in some serum electrolyte concentration.

The extract administered in this chronic toxicity study led to significant $(\mathrm{p}<0.05)$ increase in serum level of Potassium ion at $200 \mathrm{mg} / \mathrm{kg}$ and $400 \mathrm{mg} / \mathrm{kg}$ respectively while it caused a significant reduction $(\mathrm{p}<0.05)$ in serum level of Sodium ion $\left(\mathrm{Na}^{+}\right)$at $400 \mathrm{mg} / \mathrm{kg}$ dose. Hyperkalaemia is reported to occur due to severe renal injury, ketoacidosis or insulin deficiency and low levels of sodium ions reported to be caused by saltlosing nephritis, cirrhosis, gastro intestinal fluid loss and congestive heart failure [31]. The effect of these extracts at the higher doses tested on these electrolyte profile may be a pointer that the extract may be toxic to the process of electrolyte balancing in the kidney or to the functional unit of the kidney, liver, and the heart.

Histopathological studies of the liver, spleen, the kidneys, lungs, and the heart were carried out to confirm if the extract shows any morphological sign of toxicity on histoarchitecture of any of these organs. MTELE at the $200 \mathrm{mg} / \mathrm{kg}$ dose did not cause any remarkable pathological architecture of the spleen and liver but resulted to haemorrhage and vascular congestion in the kidney, heart, and the lungs. The higher dose, $400 \mathrm{mg} / \mathrm{kg}$ of MTELE caused renal, myocardial damage, fibrosis and vascular congestion in the liver, spleen and lungs. This finding confirmed the result of the biochemical assay of the indices of organ damage which pointed at the extract at $200 \mathrm{mg} / \mathrm{kg}$ and $400 \mathrm{mg} / \mathrm{kg}$ doses as a potential culprit. Fibrosis is the formation of excess connective tissue in a reparative or a reactive process. The persistent stimulus of chronic inflammation activates macrophages and lymphocytes leading to the production of growth factors and cytokine which increase the synthesis of collagen. This usually alters the architecture and affects the functions of the organ concerned. In any of these pathological situations occasioned by chronic administration of MTELE at 200 and $400 \mathrm{mg} / \mathrm{kg}$ doses, the integrity of the affected organs was compromised. This indicates that the plant extract is not harmful at $100 \mathrm{mg} / \mathrm{kg}$ body weight dosage level and can be 
safely used at dosage level much lower than $200 \mathrm{mg} / \mathrm{kg}$ body weight.

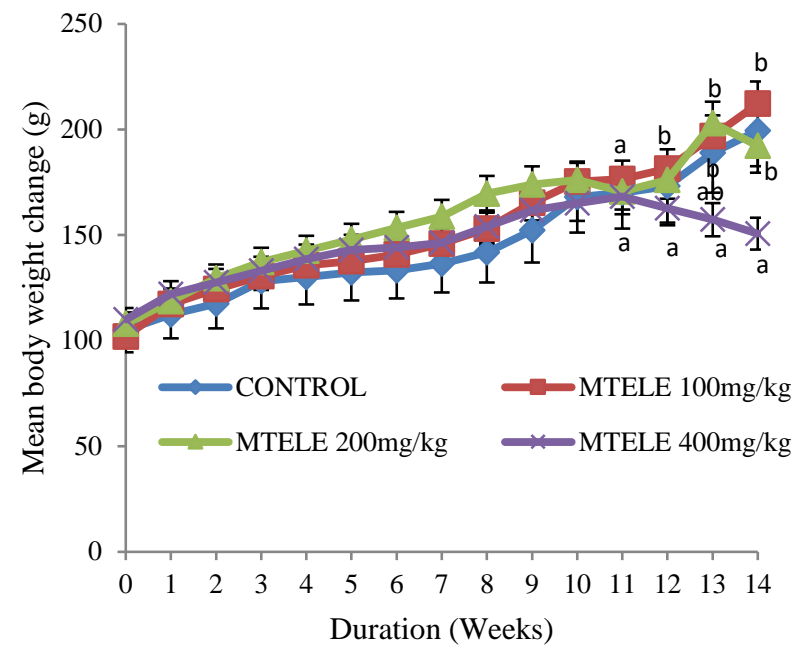

Fig 1: Effect of Administration of Ethanol Leaf Extract of M. tridentata on Mean Body Weight Change of Rats Groups for Fourteen Weeks. ${ }^{a-c}$ Values with different letters near the lines for a given week are significantly $(\mathrm{p}<0.05)$ different from each other group.
TABLE I: PHYTOCHEMICAL CONSTITUENT OF ETHANOL LEAF EXTRACT OF MERREMIA TRIDENTATA

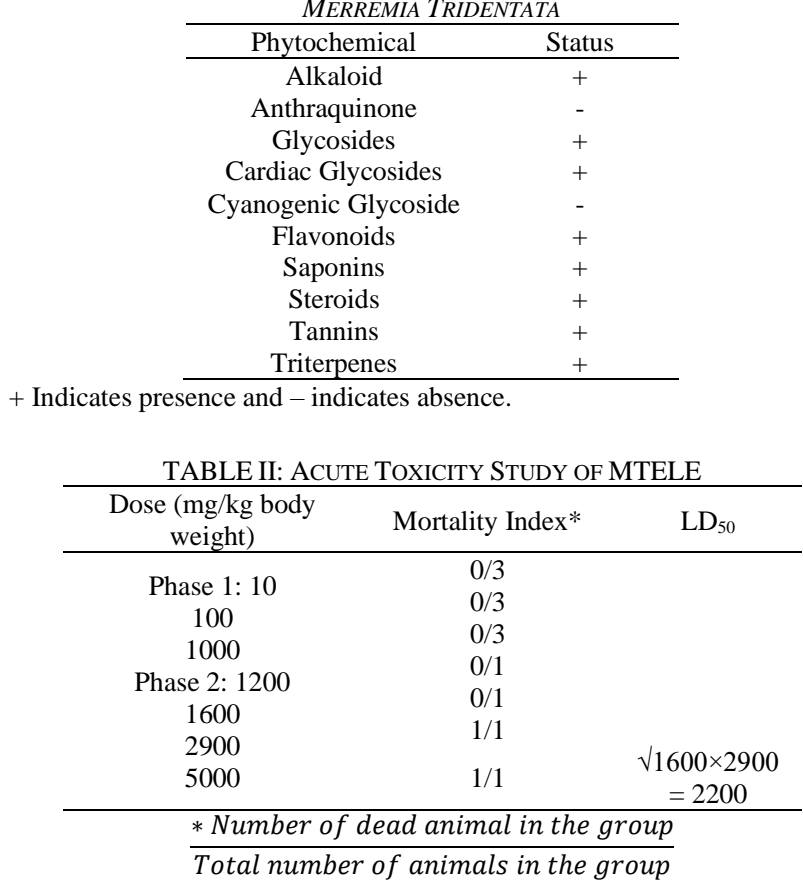

TABLE III: EFFECT OF ETHANOL LEAF AND STEM EXTRACTS OF M. TRIDENTATA ON RELATIVE ORGAN WEIGHT IN THE CHRONIC TOXICITY STUDY IN RATS

\begin{tabular}{|c|c|c|c|c|c|}
\hline Treatment & Spleen & Liver & $\begin{array}{l}\text { Kidneys } \\
(\mathrm{g} / 100 \mathrm{~g})\end{array}$ & Lung & Heart \\
\hline Normal Control & $0.30 \pm 0.05^{\mathrm{a}}$ & $3.36 \pm 0.30^{\mathrm{a}}$ & $0.43 \pm 0.05^{\mathrm{a}}$ & $0.79 \pm 0.17^{\mathrm{a}}$ & $0.42 \pm 0.05^{\mathrm{a}}$ \\
\hline $\begin{array}{c}\text { Normal Rat }+ \\
\text { MTELE }(100 \mathrm{mg} / \mathrm{kg})\end{array}$ & $0.29 \pm 0.04^{\mathrm{a}}$ & $3.24 \pm 0.26^{\mathrm{a}}$ & $0.42 \pm 0.04^{\mathrm{a}}$ & $0.78 \pm 0.16^{\mathrm{a}}$ & $0.51 \pm 0.12^{\mathrm{a}}$ \\
\hline $\begin{array}{c}\text { Normal Rat + } \\
\text { MTELE }(200 \mathrm{mg} / \mathrm{kg})\end{array}$ & $0.39 \pm 0.09^{\mathrm{a}}$ & $3.68 \pm 0.05^{\mathrm{a}}$ & $0.50 \pm 0.08^{a}$ & $1.02 \pm 0.19^{\mathrm{a}}$ & $0.62 \pm 0.16^{\mathrm{ab}}$ \\
\hline $\begin{array}{c}\text { Normal Rat }+ \\
\text { MTELE }(400 \mathrm{mg} / \mathrm{kg})\end{array}$ & $0.17 \pm 0.08^{b}$ & $4.00 \pm 0.11^{\mathrm{b}}$ & $0.93 \pm 0.13^{b}$ & $1.42 \pm 0.29^{b}$ & $0.99 \pm 0.31^{\mathrm{b}}$ \\
\hline
\end{tabular}

a-b Values expressed as Mean \pm SD of five animals with different letters along a column are significantly (p<0.05) different from each other group of animals. MTELE means $M$. tridentata ethanol leaf extract.

TABLE IV: EFFECT OF ETHANOL LEAF EXTRACT OF $M$. TRIDENTATA ON HAEMATOLOGICAL PARAMETERS IN THE CHRONIC TOXICITY STUdY In RATS

\begin{tabular}{|c|c|c|c|c|}
\hline Parameters & Normal Control & $\begin{array}{c}\text { Normal Rats }+ \\
\text { Extract }(100 \mathrm{mg} / \mathrm{kg}) \\
\end{array}$ & $\begin{array}{c}\text { Normal Rats }+ \\
\text { Extract }(200 \mathrm{mg} / \mathrm{kg}) \\
\end{array}$ & $\begin{array}{c}\text { Normal Rats }+ \\
\text { Extract }(400 \mathrm{mg} / \mathrm{kg})\end{array}$ \\
\hline Red blood cell $\left(\times 10^{6} / \mu 1\right)$ & $4.87 \pm 0.25^{\mathrm{a}}$ & $4.97 \pm 0.25^{\mathrm{a}}$ & $4.07 \pm 0.72^{\mathrm{a}}$ & $5.90 \pm 0.26^{\mathrm{a}}$ \\
\hline Haemoglobin $(\mathrm{g} / \mathrm{dl})$ & $13.50 \pm 3.44^{\mathrm{a}}$ & $13.68 \pm 2.75^{\mathrm{a}}$ & $13.87 \pm 1.43^{\mathrm{a}}$ & $15.72 \pm 1.56^{\mathrm{a}}$ \\
\hline Haematocrit $(\%)$ & $40.91 \pm 5.26^{\mathrm{a}}$ & $41.21 \pm 6.88^{\mathrm{a}}$ & $42.03 \pm 4.77^{\mathrm{a}}$ & $47.63 \pm 4.48^{\mathrm{a}}$ \\
\hline M C V (fl) & $8.40 \pm 0.46^{\mathrm{a}}$ & $8.29 \pm 0.44^{\mathrm{a}}$ & $10.32 \pm 0.54^{\mathrm{a}}$ & $8.07 \pm 0.41^{\mathrm{a}}$ \\
\hline $\mathrm{M} \mathrm{CH}(\mathrm{pg})$ & $27.72 \pm 6.08^{\mathrm{a}}$ & $27.53 \pm 4.76^{\mathrm{a}}$ & $34.07 \pm 6.43^{\mathrm{a}}$ & $26.64 \pm 10.69^{\mathrm{a}}$ \\
\hline M C H C (g/dl) & $33.00 \pm 0.00^{\mathrm{a}}$ & $33.07 \pm 0.11^{\mathrm{a}}$ & $33.00 \pm 0.00^{\mathrm{a}}$ & $33.00 \pm 0.15^{\mathrm{a}}$ \\
\hline Platelet $\left(\times 10^{5} / \mu 1\right)$ & $139.33 \pm 48.06^{\mathrm{a}}$ & $116.67 \pm 15.27^{\mathrm{a}}$ & $130.67 \pm 5.03^{\mathrm{a}}$ & $120.00 \pm 20.00^{\mathrm{a}}$ \\
\hline White blood cell $\left(\mathrm{x} 10^{3} / \mu \mathrm{l}\right)$ & $3.13 \pm 1.55^{\mathrm{a}}$ & $4.02 \pm 0.31^{\mathrm{a}}$ & $4.42 \pm 0.45^{\mathrm{a}}$ & $4.44 \pm 0.20^{\mathrm{a}}$ \\
\hline Neutrophil (\%) & $54.65 \pm 0.58^{\mathrm{a}}$ & $54.33 \pm 3.12^{\mathrm{a}}$ & $53.33 \pm 3.57^{\mathrm{a}}$ & $52.33 \pm 2.83^{\mathrm{a}}$ \\
\hline Lymphocyte (\%) & $42.63 \pm 0.57^{\mathrm{a}}$ & $42.68 \pm 1.34^{\mathrm{a}}$ & $43.32 \pm 2.55^{\mathrm{a}}$ & $46.00 \pm 3.90^{\mathrm{a}}$ \\
\hline Monocytes (\%) & $1.67 \pm 0.58^{\mathrm{a}}$ & $2.00 \pm 0.62^{\mathrm{a}}$ & $2.33 \pm 0.53^{\mathrm{a}}$ & $1.00 \pm 0.00^{\mathrm{a}}$ \\
\hline Eosinophil (\%) & $1.00 \pm 0.00^{\mathrm{a}}$ & $0.67 \pm 0.22^{\mathrm{a}}$ & $1.00 \pm 0.00^{\mathrm{a}}$ & $0.67 \pm 0.18^{\mathrm{a}}$ \\
\hline Basophil (\%) & $0.00 \pm 0.00^{\mathrm{a}}$ & $0.00 \pm 0.00^{\mathrm{a}}$ & $0.00 \pm 0.00^{\mathrm{a}}$ & $0.00 \pm 0.00^{\mathrm{a}}$ \\
\hline
\end{tabular}

${ }^{\mathrm{a}-\mathrm{b}}$ Values expressed as Mean \pm SD of five animals. Values with different letters along a row are significantly ( $\left.\mathrm{p}<0.05\right)$ different from each other. MCVMean Corpuscular volume; MCH- Mean Corpuscular Haemoglobin; MCHC- Mean Corpuscular Haemoglobin Concentration.

TABLE V: EFFECT OF ETHANOL LEAF EXTRACT OF M. TRIDENTATA ON BLOOD BIOCHEMICAL PARAMETERS IN THE CHRONIC TOXICITY STUDY IN RATS

\begin{tabular}{|c|c|c|c|c|}
\hline Parameters & Normal Control & $\begin{array}{c}\text { Normal Rats }+ \\
\text { Extract }(100 \mathrm{mg} / \mathrm{kg})\end{array}$ & $\begin{array}{c}\text { Normal Rats }+ \\
\text { Extract }(200 \mathrm{mg} / \mathrm{kg})\end{array}$ & $\begin{array}{c}\text { Normal Rats } \\
+ \text { Extract }(400 \mathrm{mg} / \mathrm{kg})\end{array}$ \\
\hline Total Protein $(\mathrm{g} / \mathrm{L})$ & $65.33 \pm 3.44^{\mathrm{a}}$ & $63.91 \pm 3.86^{\mathrm{a}}$ & $65.74 \pm 4.15^{\mathrm{a}}$ & $89.38 \pm 4.73^{\mathrm{b}}$ \\
\hline Albumin (g/L) & $36.99 \pm 3.11^{\mathrm{a}}$ & $37.26 \pm 2.74^{\mathrm{a}}$ & $35.91 \pm 1.23^{\mathrm{a}}$ & $47.34 \pm 1.32^{b}$ \\
\hline Albumin/Globulin & $1.31 \pm 0.12^{\mathrm{a}}$ & $1.44 \pm 0.29^{\mathrm{a}}$ & $1.22 \pm 0.25^{\mathrm{a}}$ & $1.13 \pm 0.06^{\mathrm{b}}$ \\
\hline Total Bilirubin (mmol/L) & $2.74 \pm 0.27^{\mathrm{a}}$ & $2.76 \pm 0.26^{\mathrm{a}}$ & $2.78 \pm 0.23^{\mathrm{a}}$ & $4.99 \pm 0.24^{\mathrm{b}}$ \\
\hline Direct Bilirubin (mmol/L) & $1.35 \pm 0.11^{\mathrm{a}}$ & $1.52 \pm 0.31^{\mathrm{a}}$ & $1.35 \pm 0.08^{\mathrm{a}}$ & $2.27 \pm 0.14^{\mathrm{b}}$ \\
\hline Urea $(\mathrm{mmol} / \mathrm{L})$ & $5.91 \pm 0.13^{\mathrm{a}}$ & $5.89 \pm 0.13^{\mathrm{a}}$ & $6.29 \pm 0.48^{\mathrm{a}}$ & $11.15 \pm 2.00^{\mathrm{b}}$ \\
\hline Creatinine $(\mathrm{mmol} / \mathrm{L})$ & $51.56 \pm 2.34^{\mathrm{a}}$ & $51.08 \pm 2.09^{\mathrm{a}}$ & $52.02 \pm 3.86^{\mathrm{a}}$ & $74.33 \pm 9.44^{b}$ \\
\hline Alkaline Phosphatase (U/l) & $61.28 \pm 3.92^{\mathrm{a}}$ & $66.20 \pm 4.67^{\mathrm{ab}}$ & $76.90 \pm 8.59^{b}$ & $116.52 \pm 14.17^{\mathrm{c}}$ \\
\hline Alanine amino transferase(U/l) & $33.40 \pm 6.40^{\mathrm{a}}$ & $32.69 \pm 4.73^{\mathrm{a}}$ & $35.66 \pm 3.87^{\mathrm{a}}$ & $46.32 \pm 6.81^{b}$ \\
\hline Aspartate aminotransferase(U/l) & $80.22 \pm 2.49^{\mathrm{a}}$ & $77.63 \pm 4.69^{\mathrm{a}}$ & $85.43 \pm 5.21^{b}$ & $84.49 \pm 3.96^{\mathrm{b}}$ \\
\hline Creatine Kinase (IU) & $0.61 \pm 0.03^{\mathrm{a}}$ & $0.57 \pm 0.05^{\mathrm{a}}$ & $0.68 \pm 0.03^{b}$ & $0.75 \pm 0.04^{\mathrm{c}}$ \\
\hline Lactate Dehydrogenase (IU) & $205.33 \pm 4.45^{\mathrm{a}}$ & $201.31 \pm 3.22^{\mathrm{a}}$ & $226.42 \pm 8.08^{\mathrm{b}}$ & $240.67 \pm 7.58^{b}$ \\
\hline Sodium Ion (mmol/L) & $140.20 \pm 3.19^{\mathrm{a}}$ & $139.00 \pm 1.92^{\mathrm{a}}$ & $139.80 \pm 1.92^{\mathrm{a}}$ & $131.80 \pm 6.30^{\mathrm{b}}$ \\
\hline Potassium Ion $(\mathrm{mmol} / \mathrm{L})$ & $4.02 \pm 0.31^{\mathrm{a}}$ & $4.06 \pm 0.32^{\mathrm{a}}$ & $4.58 \pm 0.16^{\mathrm{b}}$ & $5.30 \pm 0.37^{\mathrm{c}}$ \\
\hline
\end{tabular}

${ }^{\mathrm{a}-\mathrm{d}}$ Values expressed as Mean \pm SD of five animals. Values with different letters along a row are significantly ( $\left.\mathrm{p}<0.05\right)$ different from each other. 


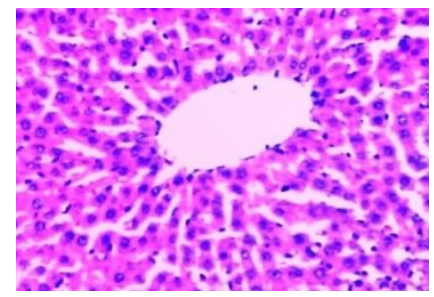

(a)

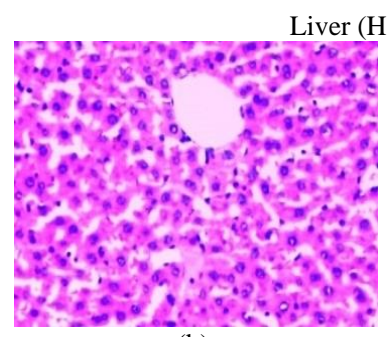

(b)

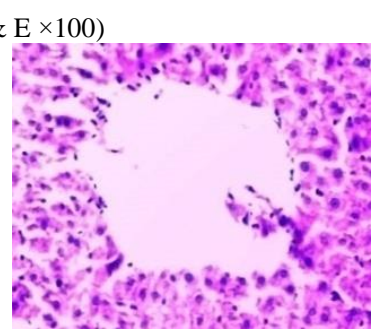

(c)

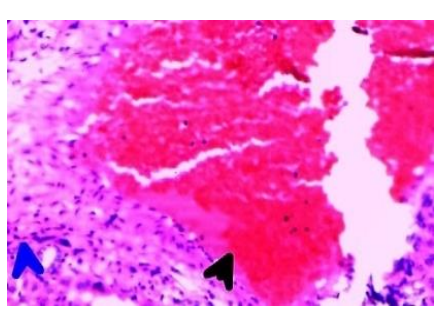

(d) Plate $1 \mathrm{a}-\mathrm{d}$. (a) Photomicrograph of the liver of a normal control rat showing normal hepatocytes arranged in polygonal unit containing a central venule, (b)
Liver of rats administered $100 \mathrm{mg} / \mathrm{kg}$ dose of $M$. tridentata ethanolic leaf extract showing intact tissue, (c)micrograph showing no damage (200 mg/kg), (d)Liver showing fibrosis and vast area of vascular congestion $(400 \mathrm{mg} / \mathrm{kg})$.

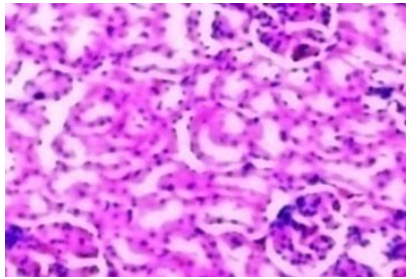

(a)

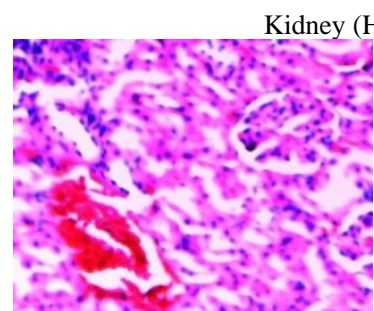

(b)

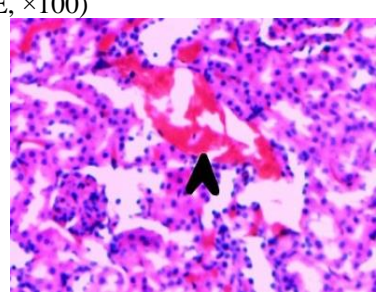

(c)

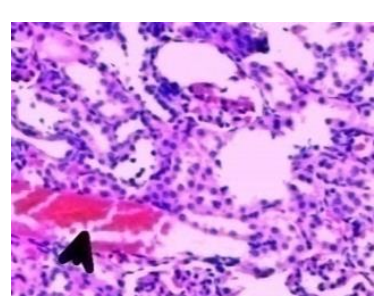

(d)

Plate 2a-d: (a) Photomicrograph of the kidney of a normal control rat showing unremarkable kidney with the cortex containing glomeruli and medullar renal tubules, (b) kidney of rat administered $100 \mathrm{mg} / \mathrm{kg}$ MTELE showing intact tissue, (c): kidney showing haemorrhage and vascular congestion at $200 \mathrm{mg} / \mathrm{kg}$ dose, (d):kidney of rat administered 40 0mg/kg MTELE showing areas of haemorrhage, vascular congestion (arrowed) and renal damage.

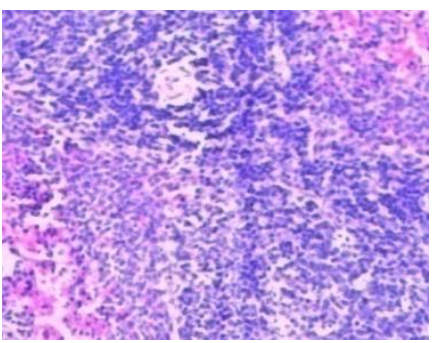

(a)

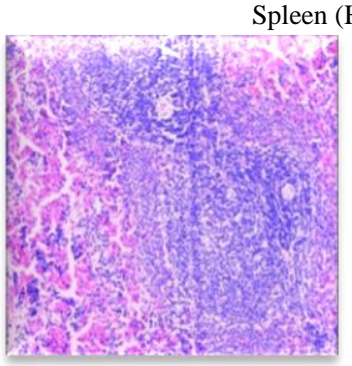

(b)

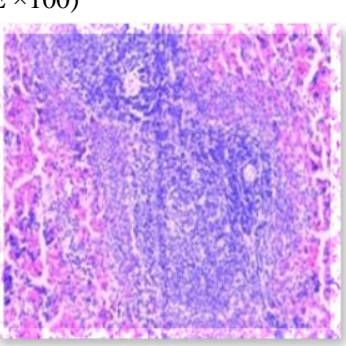

(c)

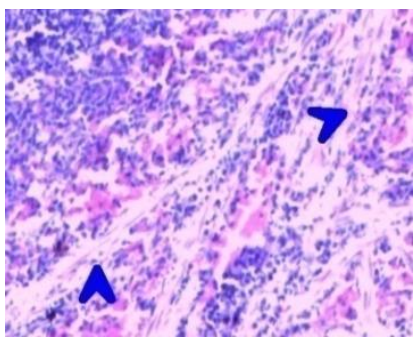

(d)

Plate3a-d. (a) Photomicrograph of control rat spleen showing the red and white pulp (Normal architecture. b \& c: spleen of rat treated with $100 \mathrm{mg} / \mathrm{kg} \&$ $200 \mathrm{mg} / \mathrm{kg}$ dose MTELE respectively showing normal architecture. (d). spleen of rats treated with $400 \mathrm{mg} / \mathrm{kg}$ dose of MTELE showing areas of fibrosis (arrowed)

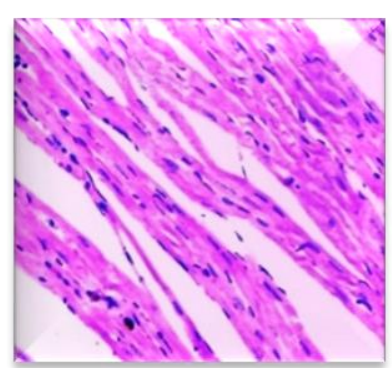

(a)

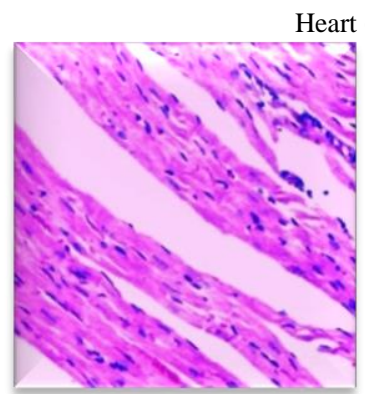

(b)

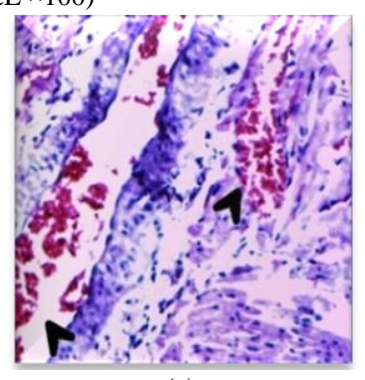

(c)

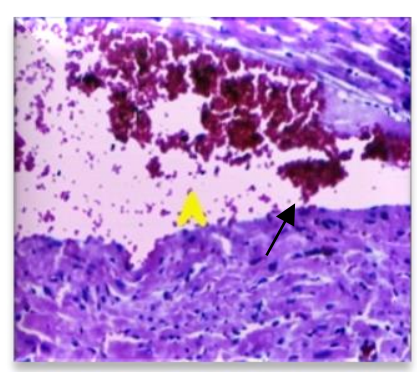

(d)

Plate 4a-d. (a \& b): Photomicrographs of the heart of a normal control rat and rat administered $100 \mathrm{mg} / \mathrm{kg}$ dose of $M T E L E$ showing an unremarkable myocardium. (c): heart of rat administered $200 \mathrm{mg} / \mathrm{kg}$ leaf extract showing haemorrhage and vascular congestion. (d): Photomicrograph of the heart of rat administered $400 \mathrm{mg} / \mathrm{kg}$ showing haemorrhage and myocardial damage.

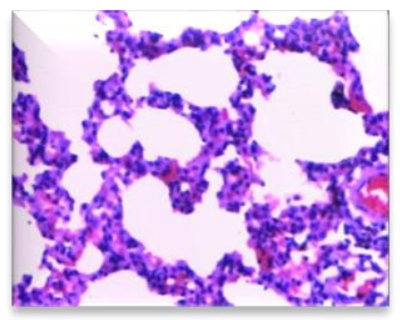

(a)

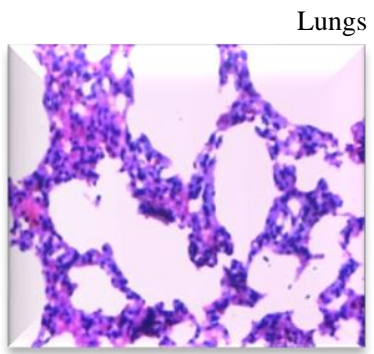

(b)

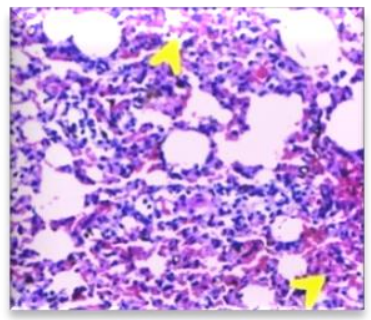

(c)

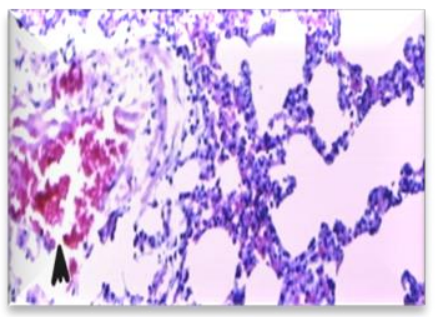

(d)

Plate $5 \mathrm{a}-\mathrm{d} /(\mathrm{a} \& \mathrm{~b})$. Photomicrographs of the lung of a normal control rat and rat administered $100 \mathrm{mg} / \mathrm{kg}$ dose of MTELE showing normal architecture. (c $\& \mathrm{~d}$ ): Photomicrographs of the lung of rats administered $200 \mathrm{mg} / \mathrm{kg} \& 400 \mathrm{mg} / \mathrm{kg}$ dose of tridentata leaf extract showing areas of haemorrhage and vascular congestion. 


\section{CONCLUSION}

Chronic administration of ethanol leaf extract of Merremia tridentata (Linn.) Hallier F. (MTELE) shows serious adverse effects on parameters such as body weight changes, relative organ weight and biochemical changes as indicated by the level of the different biomarkers of organ damage. Histopathological studies revealed different level of damage to the liver, kidney, spleen, heart, and lungs in the higher dose level tested in the study. It may be concluded that the ethanol leaf extract of Merremia tridentata (Linn.) Hallier $F$. (MTELE) may be considered relatively toxic at dosage level as low as $200 \mathrm{mg} / \mathrm{kg}$ body weight on chronic administration.

\section{REFERENCES}

[1] M.O. Soladoye and O.O Oyesiku, "Taxonomy of Nigerian Medicinal Plants" in A Textbook of Medicinal Plants from Nigeria, T. Odubgemi, Ed., Akoka-Yaba Lagos: Lagos University Press, 2008, ch 11, pp 93149.

[2] C.P. Khare, Indian Medicinal Plants: An Illustrated Dictionary. Springer, New Delhi, 2007, pp. 410-411.

[3] Sowndhararajan, K and Nyuk, L.C. (2014). Antioxidant and Anti-ulcer Effects of Ethyl Acetate Fraction of Merremia Tridentata (L.) Hallier F. Root Agriculture and Agricultural Science Procedia, 2, pp. 406414.

[4] K, Arunachalam, T, Parimelazhagan and S. Manian, Analgesic and anti-inflammatory effects of Merremia tridentata (1.) hallier f. Int $J$ Pharm Pharm Sci 2011; 3: pp75-79.

[5] K., Arunachalam, and T. Parimelazhagan, Antidiabetic activity of aqueous root extract of Merremia tridentata (L.) Hall. $f$. in streptozotocin-induced-diabetic rats. Asian Pacific Journal of tropical medicine, 2012. 5(3), pp 175-179.

[6] B.C. Hatapakki, V. Hukkeri, D.N Patil, and M.J. Chavan. Wound Healing Activity of Merremia Tridentata. Indian Drugs 2004, 41, 532.

[7] M., Kamalutheen, S., Gopalakrishnan, and T.S., Ismail,. AntiInflammatory and Anti-Arthritic Activities of Merremia Tridentata (L.) Hall. f. E. Journal of Chemistry, 2009: 6, pp 943-948.

[8] A., Aschfalk, H., Steingass, W., Muller and E. Drochner, Merremia tridentata as a Supplementary Feed to the Grass Panicum Maximum forYoung West African Dwarf Sheep. Tropical Animal Health and Production, 2002, 34, pp 45-50.

[9] D. Lorke, A new approach to practical acute toxicity testing. Archives of Toxicology, 1983, 54: pp 275-287.

[10] P. Kalaiselvi, M., Uma, M., Suresh, K. Thulasiraman, and E. Lakshmidevi, Chronic toxicity studies of aqueous leaf extract of Indian traditional medicinal plant Ocimum tenuiflorum (Linn.) in rats European Journal of Experimental Biology, 2013, 3(5): pp 240-247.

[11] Evenson M.E. (1999). "Spectrophotometric Technique". In: Tietz Textbook of Clinical Chemistry, 3rd ed, CA Burtis, ER Ashwood, Eds. Philadelphia:WB Saunders Co., pp. 75-93.

[12] J. Ochei and A. Kolhatkar, "Histopathological Techniques and Cytology”. In: Textbook of Medical Laboratory Technology- Theory and Practice, $3^{\text {rd }}$ ed. 2008, Tata McGraw-Hill Publishing Company Limited, New Delhi: pp.418 - 426.

[13] C.A. Pieme, V.N. Penlap, B. Nkegoum, C.L. Taziebou, E.M. Tekwe, F.X. Etoa and J. Ngongang, Evaluation of acute and subacute toxicities of aqueous ethanol extract of leaves of Senna alata (L.) Roxb (Ceasalpiniaceae). Afriican Journal of Biotechnology, 2006, 5(3): pp. 283-289.
[14] K.C. Patrick-Iwuanyanwu, M.O. Wegwu and J.K. Okiyi Hepatoprotective effects of African locust bean (Parkia clappertoniana) and negro pepper (Xylopia aethiopica) in CCl4 induced liver damage in Wistar albino rats. International Journal of Pharmaceutics 6, 2010, pp.744-749.

[15] S. Kumar, P.Singh, G. Mishra, S. Srivastar, KK. Jha, RL. Khosa, Phytopharmacological review of Alternanthera brasiliana (Amaranthaceae). Asian Journal of Plants Science Research, 2011.1(1): pp.41- 47.

[16] C.U. Osifo, U. Akpamu, C.I. Idehen, W.A. Adisa, and K.E. Azeke, The effect of chronic ingestion of crude garcinia kola on the histology of the liver, European Journal of. Experimental Biology, 2012. 2 (2): pp.404-409.

[17] S.O. Ogbonnia, S, G.O. Mbaka, F.E. Nkemehule, J.E. Emordi, N.C. Okpagu and D.A. Ota, Acute and subchronic evaluation of aqueous extracts of Newbouldia laevis (Bignoniaceae) and Nauclea latifolia (Rubiaceae) roots used singly or in combination in Nigerian traditional medicines. British Journal of Pharmacology and Toxicology., 2014. 5(1): pp. 55-62.

[18] W.J. Brock, H.J. Trochimowicz, R.J. Millischer, C. Farr, T. Kawano and G.M. Rusch, Acute and subchronic toxicity of 1,1-dichloro-1fluoroethane (HCFC-141b). Food and Chemical Toxicology, 1995. 33, pp. $483-490$.

[19] A.J. Fridous, S. N. L. M. Islam and A.B.M. Faruque, Antimicrobial activity of the leaves of Adhatoda vasica, Calotropis gigantea, Nerium odorum and Ocimum sanctum. Bangladesh. Journal of Botany. 1990. 19: 227-229.

[20] G.V. Pierangeli and L.R Windell, Antimicrobial activity and cytotoxicity of Chromolaena odorata (L. f). King and Robinson and Uncaria perrottetii (A. Rich) Merr. extracts. Journal Medicinal Plants Research, 2009. 3(7): pp.511-518.

[21] M. Raza, O.A. Al-Shabanah, T.M. El-hadiyah and A.A. Al-Majed Effect of Prolonged Vigabatrin Treatment on Hematological and Biochemical Parameters in Plasma, Liver and Kidney of Swiss Albino Mice. Scientia Pharmaceutica, 2002, 70, pp. 135-145.

[22] S.K. Thanabhorn, S. Jenjoy, K. Thamaree, K. Ingkaninan and A. Panthong, Acute and subacute toxicity study of the ethanol extract from Lonicera japonica Thunb. Journal of. Ethnopharmacol., 2006. 107: pp. 370-373.

[23] R. Nirogi, V.K. Goyal, S. Jana, S.K. Pandey, and A. Gothi, What suits best for organ weight analysis: review of relationship between organ weight and body / brain weight for rodent toxicity studies International Journal of Pharmaceutical Science and Research, 2014, Vol. 5(4): 1525-1532.

[24] S.A Bailey, R.H. Zidell and R.W. Perry, Relationships between organ weight and body/brain weight in the rat: What is the best analytical endpoint? Toxicol. Pathol. 2004. 32, 448-466.

[25] H. Rhiouani, J. El-Hilalya, Z.H. Israili and B. Lyoussia, Acute and Sub-chronic toxicity of an aqueous extract of the leavesof Herniara glabra in rodents. Journal of Ethnopharmacology, 2008, 118, 378-386.

[26] R.K Koshy, B.R Kapoor and M. Azmathulla, 2010. Pharmacology online, 3, pp. 229-242.

[27] D.W. Martin P.A. Mayes and Y.M. Rodwell, In:Harper's Review of Biochemistry. 18th edn, Lange Medical, CA, 1981, pp:61.

[28] R. Horton, L.A. Moran, R. Ochs, J.D. Rawn and K.G.Scrimgeour, Principles of Biochemistry. $2^{\text {nd }}$ Edn., 1996, Prentice Hall.

[29] K.M. Wasan, S. Najafi, J. Wong, and M. Kwong Assessing plasma lipid levels, body weight and hepatic and renal toxicity following chronic oral administration of a water soluble phytostanol compound. Journal of Pharmaceutical Science., 2001.4(3): 228-234.

[30] M.A. Crook, Clinical Chemistry and Metabolic Medicine. 7th Edn., Hodder Arnold, London, 2006. pp: 426.

[31] J. Ochei and A. Kolhatkar, Textbook of Medical Laboratory Technology- Theory and Practice, $3^{\text {rd }}$ ed. 2008, Tata McGraw-Hill Publishing Company Limited, New Delhi: pp.180-182. 